\title{
Research on Wheat Straw Pulping with lonic Liquid 1-Ethyl-3-Methylimidazole Bromide
}

\author{
W. Song, ${ }^{a}$ Y. Deng, ${ }^{b^{*}}$ and H. Zhu ${ }^{\mathrm{c}}$ \\ a Tianjin Key Laboratory for Control Theory \& Applications in Complicated Systems, \\ Tianjin University of Technology, Tianjin, 300 384, P.R. China \\ b Tianjin Key Laboratory of Pulp \& Paper, Tianjin University of Science \& Technology, \\ Tianjin, 300 457, P.R. China \\ 'Institute of Biology and Environment Engineering, Tianjin Vocational Institute, \\ Tianjin 300 410, P.R. China
}

\begin{abstract}
\| Abstract
In this paper, the pulping process of wheat straw using ionic liquid 1-ethyl-3-methylimidazolium bromide ([Emim]Br) as the digestion liquor is presented. The influence of pulping conditions on the pulp yield are analysed by single-factor and orthogonal experiments, and optimum pulping conditions are obtained. The average pulp yield reaches $44 \%$, and the average recovery rate of ionic liquid is $93.5 \%$. The XRD pattern shows no obvious change in the crystal structure of the wheat straw cellulose. Additionally, the SEM image illustrates that there are many fine fibres in the pulp and the spaces between the fibres are large.
\end{abstract}

\| Keywords

Pulping process, pulp yield, ionic liquid, recovery rate, wheat straw

\section{Introduction}

The conventional pulping process is an ordinary technique applied to non-wood fibre pulping processes. ${ }^{1-3}$ This method is not only a waste of chemicals, causes higher energy loss and heavier pollution, but also takes a long reaction time, has low pulp yield, and is expensive. It severely hinders the development of the pulp and paper industry. ${ }^{4-8}$ In order to achieve the comprehensive utilization of lignin as well as to solve common issues of high temperature, high pressure, low pulp yield, and severe pollution in the traditional chemical pulping processes, ionic liquid is chosen as the digestion liquor or pretreatment agent, and is considered to be beneficial for the pulping process. The ionic liquid can dissolve natural cellulose, a major constituent of non-wood raw materials, like wheat straw, rice straw, bagasse etc. ${ }^{9-11}$ Swatloski $i^{12}$ investigated the dissolution of cellulose in a variety of ionic liquids with different anion-cation combinations, and concluded that ionic liquid consisting of imidazolium cation and coordination anion, is more effective in dissolving cellulose than others. In this paper, we discuss the pulping technology of ionic liquid [Emim] Br. Optimum conditions for wheat straw pulping are obtained by analysing the influences of pulping variables by means of single-factor and orthogonal experiments. [Emim] Br has a low cost, it is easily prepared, and its average recovery rate reaches $93.5 \%$. That makes the entire pulping process generate almost no waste liquid (compared to the conventional methods). The physical performances of the paper sheet are tested, and the crystal structure of the cellulose and fibre morphology after the pulping is studied. The results show that the pulping process of wheat straw using

* Corresponding author: Yu Deng, Master e-mail: dengyunew@sina.com ionic liquid is consistent with that of the non-wood fibre pulping. Overall, this research provides a new idea and approach for pulp and papermaking technology.

\section{Experimental}

\subsection{Materials}

$\mathrm{N}$-methylimidazole (chemically pure) was provided by Tianjin Chemical Reagent wholesale department, ethyl bromide of analytical regent (AR) grade was purchased from Tianjin Fu Chen Chemical Reagent Factory, and the ethylenediamine copper(II) solution and wheat straw consisting of water $6.57 \%$, cold water drawn out matter $10.36 \%$, hot water $18.20 \%$, $1 \%$ sodium hydroxide taken matter $46.13 \%$, benzyl-alcohol content $1.99 \%$, holocellulose $71.37 \%$, cellulose $38.76 \%$, and lignin $15.90 \%$, was obtained from Tianjin key Laboratory of Pulping and Papermaking at Tianjin University of Science and Technology.

\subsection{Synthesis of ionic liquid}

Weigh out $\mathrm{N}$-methylimidazole and ethyl bromide in a amount ratio of $1: 1.3$ and mix them in a four-necked flask. The mixture is heated to reflux with simultaneous mechanical stirring in a water bath until the temperature slowly reaches $60{ }^{\circ} \mathrm{C}$. The liquor turns turbidity from colourless bit by bit, and finally the light yellow transparent liquid is obtained, the viscosity of which grows step by step. When the reacting time reaches 3 hours, heating is stopped and the residual ethyl bromide is wiped off by distilling. A light yellow or colourless transparent liquid is formed, which is 
left to stand for a certain period of time until the whiteness or light yellow crystals (i.e. [Emim]Br) separate out. The average yield can be stable at around $94.31 \%$. Although imidazolium-based ionic liquids are now known as rather toxic solvents, they are used because of their easy preparation and high performance.

\subsection{Wheat straw cooking ${ }^{13}$}

Cut $20 \mathrm{~g}$ (dry weight) wheat straw into $2-3 \mathrm{~cm}$ fragments and put them with digestion liquor ionic liquid in a digester in accordance with a specific liquid-solid $(m(\mathrm{~L}): m(\mathrm{~S})$ from $10: 1$ to $4: 1$ ). The range of cooking temperature is $80-150{ }^{\circ} \mathrm{C}$, and the cooking time varies from 10 to 40 minutes. The influences of cooking variables on pulp yield under atmospheric pressure are analysed, and the pulp yield can be calculated using the following equation (Eq. 1).

$$
\text { pulp yield }=\frac{\begin{array}{c}
\text { coarse pulp } \\
\text { wet weight }
\end{array} \times\left(1-\begin{array}{c}
\text { mass fraction of } \\
\text { water in coarse pulp }
\end{array}\right)}{\text { wheat straw dry weight }}
$$

Note: the water content of the coarse pulp is determined by drying the samples to a constant mass (accuracy: $0.0001 \mathrm{~g}$ ) in an oven $\left(105^{\circ} \mathrm{C}\right)$.

\subsection{Lignin separation and ionic liquid recycling}

After cooking, the wheat straw pulp is put into a 200-mesh filter bag, and then separated from the ionic liquid. The wheat straw pulp is then rinsed repeatedly with conductivity water. The liquid phase is transferred into a beaker, left to stand for a certain time until the sediment is dissolved out, followed by centrifugal separation. These precipitates are first treated with alkaline solution, then a separation process, and finally an acidic solution. The $\mathrm{pH}$ of the filtrate is adjusted to neutral after the separation and the lignin is separated out again in this neutral solution. Precipitated lignin is washed thoroughly with conductivity water, dried, and weighed. Additionally, the ionic liquid is recovered by filtering, washing, distillation, drying, and weighing after cooking. The whole flow diagram of wheat straw pulping with ionic liquid is shown in Fig. 1.

\subsection{Paper physical properties test}

Using a standard paper sheet forming device (7407S, Mavis Engineering Ltd, UK), the ration of papermaking is $60 \mathrm{~g} \mathrm{~m}^{-2}$ page sheet according to the TAPPI method. The formed paper sheet is dried on a drum dryer after going through 5 min front and $3 \mathrm{~min}$ back surfaces press. The handsheet is placed in an environment of constant temperature and humidity $\left(23 \pm 1{ }^{\circ} \mathrm{C}\right.$; relative humidity $\left.50 \pm 2 \%\right)$ for 4 hours, and then tested for its physical performances. According to the national standard GB/T 2679.5-1995/1989, the paper physical properties are tested by Swedish L\&W company determinators of bursting strength, tearing strength and breaking length.

In these experiments, ethylenediamine copper(II) solution is adopted as a solvent to dissolve cellulose and the relative viscosity $\eta$ is measured by the capillary viscometer. Then intrinsic viscosity $[\eta]$ is obtained by Martin empirical formula (Eq. 2):

$$
\lg \frac{\eta-\eta_{0}}{\eta_{0} C}=\lg [\eta]+K[\eta] C
$$

where $C$ is the cellulose concentration (in $\mathrm{g} /(100 \mathrm{ml})$ ) in ethylenediamine copper(II) solution (oven-dried), and $K=0.13$ is the constant for ethylenediamine copper(II) solution.

The computational formula of pulp polymerization degree (DP) is as follows:

$$
\mathrm{DP}^{0.905}=0.75[\eta]
$$

where $[\eta]$ is intrinsic viscosity in units $\mathrm{mlg}^{-1}$.

\subsection{SEM scanning and XRD diffraction analysis}

XRD (TD-3500, Dandong Tongda Technology Co., LTD, China) surveys cellulose crystal type changes after cooking pulping. The fibre structure and morphology characteristics of wheat straw can be observed by SEM scanning (EM-30, Beijing Kusaimu Scientific Instruments Marketing Center, China) as well as a Universal Research Microscope after ionic liquid cooking pulping.

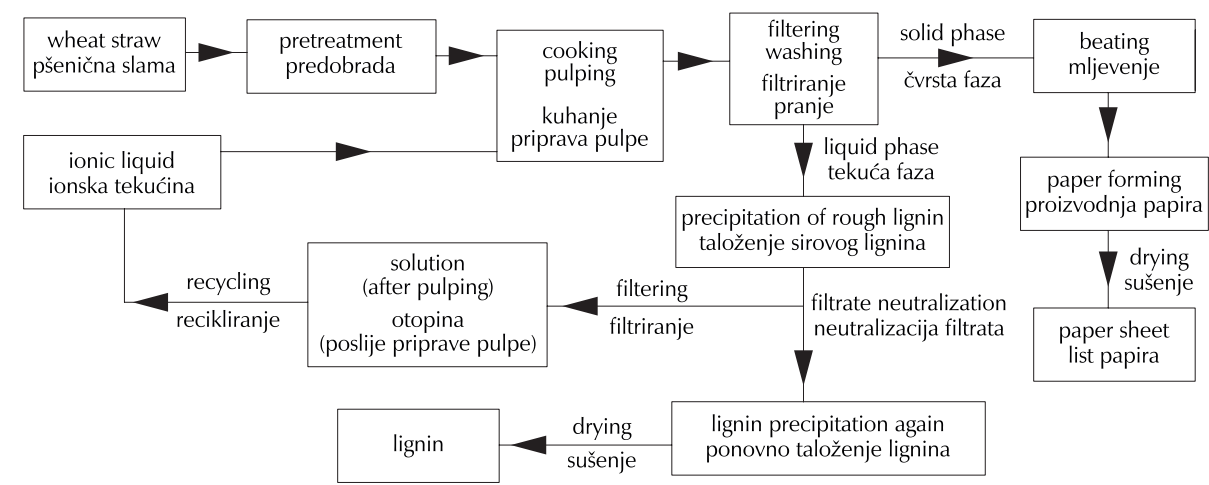

Fig. 1 - Flow diagram of pulping process

Slika 1 - Dijagram toka priprave pulpe 


\section{Results and discussion}

\subsection{Single-factor experiment}

\subsubsection{The effect of ratio $m(\mathrm{~L}): m(\mathrm{~S})$ on the pulp yield}

The effect of different $m(\mathrm{~L}): m(\mathrm{~S})$ (ionic liquid vs. wheat straw) on the pulp yield is shown in Fig. 2, where the cooking temperature is $140{ }^{\circ} \mathrm{C}$ and the cooking time is 30 min. When $m(\mathrm{~L}): m(\mathrm{~S})$ is smaller than $4: 1$, it is difficult for the ionic liquid, as cooking solvent, to fully infiltrate the wheat straw and dissolve the lignin, resulting in a low pulp yield. When the ratio $m(\mathrm{~L}): m(\mathrm{~S})$ increases, the pulp yield first increases and then decreases. In particular, when the $m(\mathrm{~L}): m(\mathrm{~S})$ is $6: 1$, the pulp yield reaches its maximal value. We think that the excessive ionic liquid might damage wheat straw fibres. Usually, more ionic liquid leads to more biomass dissolution due to reduction in viscosity and other factors, which means less pulp yield. Therefore, a $m(\mathrm{~L}): m(\mathrm{~S})$ ratio ranging from $9: 1$ to $6: 1$ is suitable for pulping (of wheat straw) in ionic liquid.

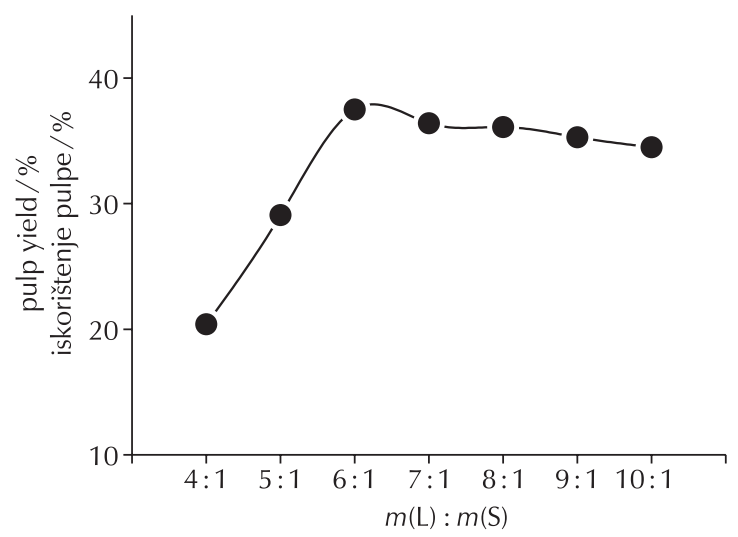

Fig. 2 - Effect of $m(\mathrm{~L}): m(\mathrm{~S})$ ratio on the pulp yield

Slika 2 - Utjecaj omjera $m(\mathrm{~L}): m(\mathrm{~S})$ na iskorištenje pulpe

\subsubsection{Effect of the cooking temperature on the pulp yield}

The effect of different cooking temperatures on pulp yield is investigated when the $m(\mathrm{~L}): m(\mathrm{~S})$ ratio is $6: 1$ and the cooking time is $30 \mathrm{~min}$, and the results are shown in Fig. 3. The pulp yield increases with the increase in cooking temperature, however, it begins to drop when the cooking temperature is higher than $140{ }^{\circ} \mathrm{C}$. Generally speaking, the dissolving capacity of various substances increases with the rise in temperature. Before $140{ }^{\circ} \mathrm{C}$, the amount of dissolved lignin increases, which makes beating easy, so pulp yield is rising. After $140{ }^{\circ} \mathrm{C}$, the pulp yield begins to drop. This means that too high temperatures could damage cellulose in wheat straw pulping. According to the literature, ${ }^{14-16}$ the straw lignin is comprised of many phenolic hydroxyl and carboxyl groups, and many p-hydroxyphenyl units connect with other lignin structure units via ester bonds. Under moderate conditions, the ester bond in lignin might be totally fractured, and $\alpha$-ether bond can be partially broken, which makes the straw lignin fragmented and easily dissolved. Therefore, a suitable cooking temperature should be used to ensure a sufficient delignification rate in the pulping process, that is, to decrease the rate of breakdown of cellulose. With comprehensive consideration of the pulp yield and separation of lignin, $120-140{ }^{\circ} \mathrm{C}$ is selected as proper cooking temperature.

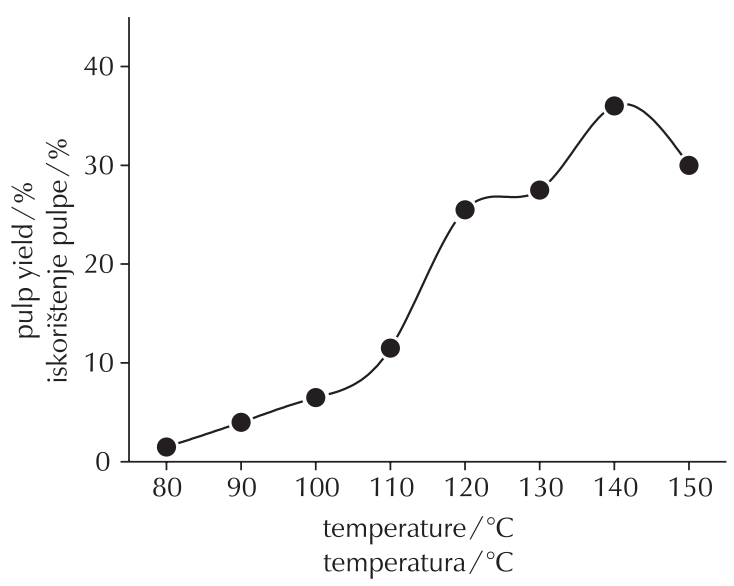

Fig. 3 - Effect of temperature on the pulp yield Slika 3 - Utjecaj temperature na iskorištenje pulpe

\subsubsection{Effect of cooking time on pulping of wheat straw in ionic liquid}

The effect of various cooking time on the pulp yield is shown in Fig. 4, where the ratio $m(\mathrm{~L}): m(\mathrm{~S})$ is $6: 1$ and the cooking temperature is $140{ }^{\circ} \mathrm{C}$. The pulp yield first increases with the increase in cooking time, and then levels off. The pulp yield reaches its highest value when the cooking time is $25 \mathrm{~min}$. Wheat straw pulping is in the quickly dissolving phase during $10-20 \mathrm{~min}$, and a number of lignin is dissolved out at this phase. The tendency levels off bit by bit after 25 min. Theoretically, with longer cooking time, the pulping reaction is more thorough and the delignification is more significant.

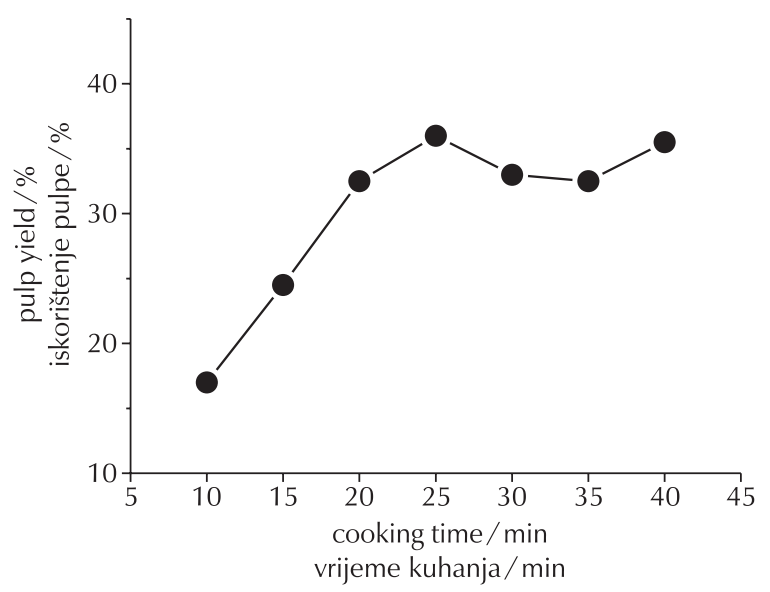

Fig. 4 - Effect of cooking time on pulp yield

Slika 4 - Utjecaj trajanja kuhanja na iskorištenje pulpe

However, in the late stage of pulping, that is, after most of the lignin is separated out, the macromolecules of cellulose 
are entirely exposed in the ionic liquid, which causes the cellulose to degrade easily, leading to reduced productivity as well as increased energy consumption. The cooking time scope of the choice is also based on easy beating and makes pulp yield high. So, with the comprehensive consideration of the pulp yield and benefit, 20-30 min is selected as the appropriate cooking time.

\subsection{Orthogonal experiments}

An orthogonal table is designed, where the factor 'level' is introduced along with wheat straw cooking conditions in single factor experiments (Table 1). In this table, the liquid-to-solid ratio $m(\mathrm{~L}): m(\mathrm{~S})$ is between $9: 1$ and $6: 1$, the cooking temperature is $120-140{ }^{\circ} \mathrm{C}$, and the cooking time varies from $20 \mathrm{~min}$ to $30 \mathrm{~min}$.

Table 1 - Basic factors of orthogonal experiments

Tablica 1 - Osnovni parametri ortogonalnih eksperimenata

\begin{tabular}{l|c|c|c}
\hline $\begin{array}{l}\text { Level } \\
\text { Razina }\end{array}$ & 1 & 2 & 3 \\
\hline $\begin{array}{l}\text { cooking time } / \mathrm{min} \\
\text { vrijeme kuhanja/min }\end{array}$ & 20 & 25 & 30 \\
$\begin{array}{l}\text { temperature } /{ }^{\circ} \mathrm{C} \\
\text { temperatura } /{ }^{\circ} \mathrm{C}\end{array}$ & 120 & 130 & 140 \\
$m(\mathrm{~L}): m(\mathrm{~S})$ & $6: 1$ & $8: 1$ & $9: 1$ \\
\hline
\end{tabular}

The experimental data are processed according to the pulp yields, and the results of orthogonal experiments are shown in Table 2.

Table 2 - Orthogonal experiment results

Tablica 2 - Rezultati ortogonalnih eksperimenata

\begin{tabular}{c|c|c|c|c}
\hline $\begin{array}{c}\text { No. } \\
\text { Br. }\end{array}$ & $\begin{array}{c}\text { Time } / \text { min } \\
\text { Vrijeme } \\
\text { min }\end{array}$ & $\begin{array}{c}\text { Temperature } /{ }^{\circ} \mathrm{C} \\
\text { Temperatura } /{ }^{\circ} \mathrm{C}\end{array}$ & $m(\mathrm{~L}): m(\mathrm{~S})$ & $\begin{array}{c}\text { Pulp yield } \\
\% \% \\
\text { Iskorištenje } \\
\text { pulpe } / \%\end{array}$ \\
\hline 1 & 1 & 1 & 1 & 8.0 \\
2 & 1 & 2 & 2 & 27.5 \\
3 & 1 & 3 & 3 & 34.5 \\
4 & 2 & 1 & 2 & 25.0 \\
5 & 2 & 2 & 3 & 23.0 \\
6 & 2 & 3 & 1 & 39.5 \\
7 & 3 & 1 & 3 & 13.0 \\
8 & 3 & 2 & 1 & 34.0 \\
9 & 3 & 3 & 2 & 36.5 \\
$\mathrm{~K}_{\mathrm{I}}$ & 34.5 & 46.0 & 81.5 & \\
$\mathrm{~K}_{\text {II }}$ & 39.5 & 84.5 & 89.0 & \\
$\mathrm{~K}_{\text {III }}$ & 36.5 & 110.5 & 70.5 & \\
$\mathrm{R}$ & 5.0 & 64.5 & 18.5 & \\
\hline
\end{tabular}

The influencing degree of diversified factors on pulp yields was obtained based on pulp yields and the values of range $\mathrm{R}$. That is reacting temperature $>m(\mathrm{~L}): m(\mathrm{~S})>$ reacting time. From all the experiments, experiment No. 6 shows the highest pulp yield, which is up to $39.5 \%$, so $A_{2} B_{3} C_{2}$ is identified as the best combination of pulping conditions. Therefore, we draw a conclusion that the optimum conditions of the pulping process can be characterized by a $m(\mathrm{~L}): m(\mathrm{~S})$ ratio of $8: 1$, a cooking temperature of $140{ }^{\circ} \mathrm{C}$, and a cooking time of $25 \mathrm{~min}$.

\subsection{Validation experiments}

Verification experiments are conducted under optimum conditions for three times, and the results are shown in Table 3. The average pulp yield reaches $44 \%$, and the mean recovery of ionic liquid reaches $93.5 \%$ considering all three parallel experiments.

Table 3 - Results of validation experiments

Tablica 3 - Rezultati validacijskih eksperimenata

\begin{tabular}{c|c|c}
\hline $\begin{array}{c}\text { No. } \\
\text { Br. }\end{array}$ & $\begin{array}{c}\text { Pulp yield } / \% \\
\text { Iskorištenje pulpe } / \%\end{array}$ & $\begin{array}{c}\text { lonic liquid recovery } / \% \\
\text { Povrat ionske tekućine } / \%\end{array}$ \\
\hline 1 & 40.58 & 92.7 \\
2 & 45.98 & 95.2 \\
3 & 45.44 & 92.6 \\
$\begin{array}{c}\text { average } \\
\text { prosjek }\end{array}$ & 44 & 93.5 \\
\hline
\end{tabular}

The pulp yields of cooking wheat straw in ionic liquid are high because of the unique nature of ionic liquid dissolved lignin. Ionic liquid as a digestion liquor can be recycled, which compensates its expensiveness. Moreover, ionic liquid makes the pulping process free of pollution (i.e., no black liquor). The anion of ionic liquid [Emim] Br in the boiling solvent has a good coordination ability. It is easy to immerse in the three-dimensional network structure of lignin and break intermolecular and intramolecular hydrogen bonding in lignin. As a result, [Emim] Br is effective in dissolving lignin. While cation [Emim] ${ }^{+}$itself contains strong polarity double bonds, the $\mathrm{H}$ atoms in the cation [Emim] ${ }^{+}$ and the hydroxyl in the lignin also form hydrogen bonds, further reducing the acting force between the lignin units and the molecules. ${ }^{17-19}$ In addition, the special chemical structure of [Emim] $\mathrm{Br}$ and its pure ion environment could also reduce the interaction between lignin macromolecules, which enables the lignin to dissolve better. According to the characteristics of straw lignin, moderate neutral ionic liquids not only dissolve the lignin quickly, but also reduce the damage to cellulose, resulting in an increased pulp yield.

\subsection{Paper sheet performance test}

The average physical performance parameter values of ordinary paper with chemical pulp in laboratory (beating 
degree $45^{\circ} \mathrm{SR}$ ) are as follows: tightness $0.57 \mathrm{~g} \mathrm{~cm}^{-3}$, breaking length $1.93 \mathrm{~km}$, tearing strength $2.0 \mathrm{mN} \mathrm{m}^{2} \mathrm{~g}^{-1}$, bursting strength $1.5 \mathrm{kPa} \mathrm{m}^{2} \mathrm{~g}^{-1}$, and tensile index $45.0 \mathrm{~N} \mathrm{mg}^{-1}$. Paper sheet performance tests include pulp defibering, beating $\left(45^{\circ} \mathrm{SR}\right)$, and handsheet. The paper sheet used in the validation experiment is shown in Fig. 5, physical performances of which were tested after the paper sheet had been treated under constant temperature and humidity.

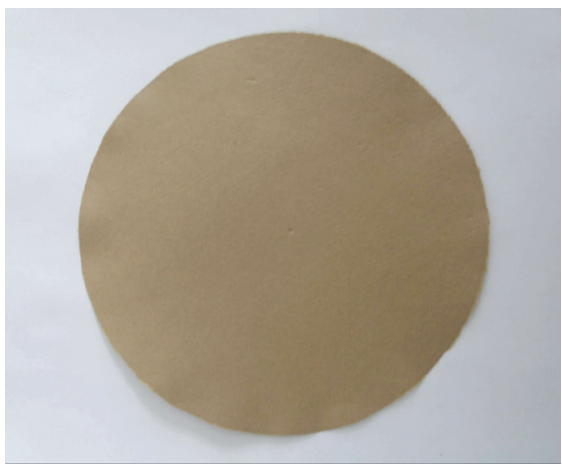

Fig. 5 - Image of the paper used in validation experiment

Slika 5 - Fotografija papira upotrijebljenog u validacijskom eksperimentu

The experimental results, shown in Table 4, indicate that the physical properties of the paper from the ionic liquid wheat straw pulping process meets the requirements of regular paper.

Table 4 - Paper sheet performance data

Tablica 4 - Svojstva papira

\begin{tabular}{l|c}
\hline $\begin{array}{l}\text { tightness } \\
\text { gustoća }\end{array}$ & $0.547 \mathrm{~g} \mathrm{~cm}^{-3}$ \\
\cline { 1 - 1 } $\begin{array}{l}\text { breaking length } \\
\text { prekidna duljina }\end{array}$ & $1.61 \mathrm{~km}$ \\
\hline $\begin{array}{l}\text { degree of polymerization } \\
\text { stupanj polimerizacija }\end{array}$ & 724.90 \\
\hline $\begin{array}{l}\text { tearing strength } \\
\text { rastezna čvrstoća }\end{array}$ & $1.43 \mathrm{mN} \mathrm{m}^{2} \mathrm{~g}^{-1}$ \\
\hline $\begin{array}{l}\text { bursting strength } \\
\text { otpornost na probijanje }\end{array}$ & $0.59 \mathrm{kPa} \mathrm{m}^{2} \mathrm{~g}^{-1}$ \\
\hline $\begin{array}{l}\text { tensile index } \\
\text { indeks cijepanja }\end{array}$ & $44 \mathrm{~N} \mathrm{~m} \mathrm{~g}^{-1}$ \\
\hline
\end{tabular}

\section{3. $5 X R D$ radial diffraction experiment}

Fig. 5 shows the results of XRD diffraction analysis of wheat straw pulp fibres after [Emim]Br pulping. The XRD pattern shows two diffraction peaks in Fig. $6\left(2 \theta=15.298^{\circ}\right.$, $2 \theta=21.844^{\circ}$ ), whose characteristics are consistent with those given by the standard XRD spectrum of native cellulose. ${ }^{20}$ This result illustrates that the crystal structure of cellulose in wheat straw is not obviously changed after pulp- ing in ionic liquid, and the pulping process is mild enough not to damage the cellulose.

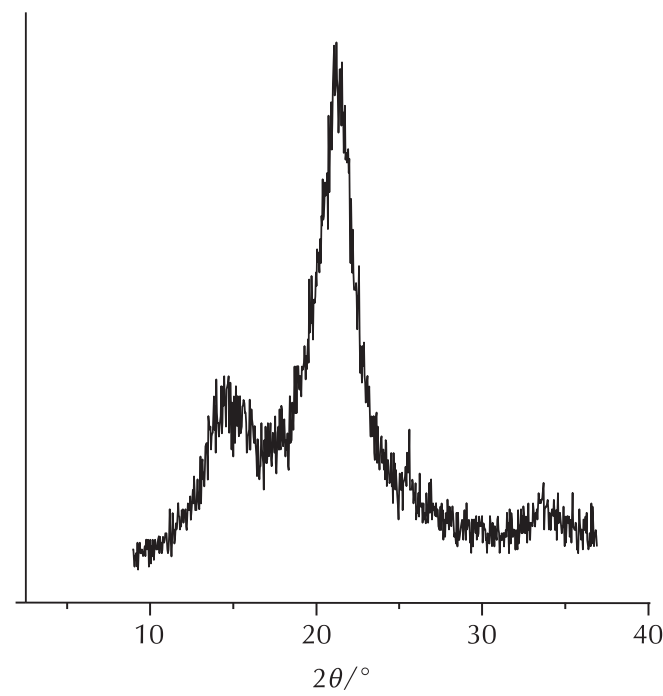

Fig. 6 - XRD pattern of pulp fibres

Slika 6 - Rendgenogram vlakana u pulpi

\subsection{Pulp fibre SEM scanning}

The morphology of wheat straw fibres after cooking is studied by SEM, which is shown in Fig. 7. It could be seen that the pulp fibres are devillicated and the fibre cell walls are damaged. In addition, there are many exposed fine fibres, and the spaces between fibres are larger. The characteristics of ionic liquid cooking wheat straw pulping are consistent with those of straw pulp.

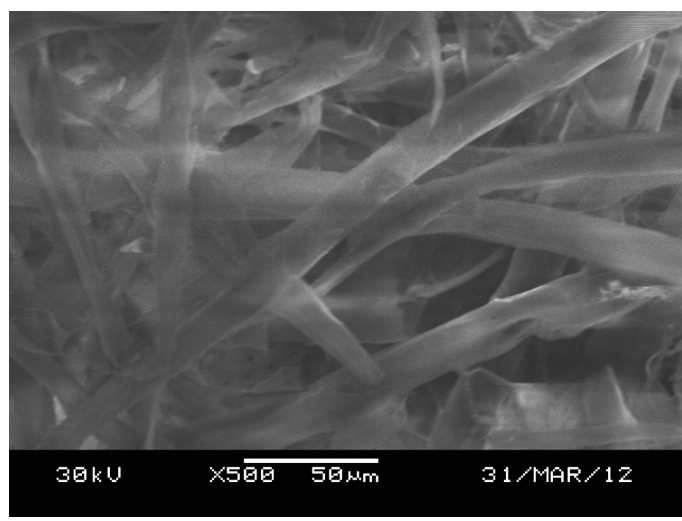

Fig. 7 - SEM image of pulp fibres

Slika 7 - Elektronska mikrografija vlakana pulpe

\section{Conclusions}

(1) Optimum conditions for the pulping process of wheat straw in ionic liquid [Emim] $\mathrm{Br}$ (as digestion liquor) are obtained by single-factor and orthogonal experiments. The 
optimum cooking temperature is $140{ }^{\circ} \mathrm{C}$, the desired cooking time is $25 \mathrm{~min}$, and the most suitable liquid-to-solid mass ratio $m(\mathrm{~L}): m(\mathrm{~S})$ (ionic liquid vs. wheat straw) is $8: 1$.

(2) Verification experiments are conducted, and the average pulp yield is $44 \%$, which is higher than that of traditional chemical pulping. The average recovery rate of ionic liquid [Emim] $\mathrm{Br}$ is $93.5 \%$, and the entire pulping process generates no waste liquid. Test data indicate that the physical properties of the fabricated papers meet the requirements of regular paper.

(3) Ionic liquid [Emim]Br is effective in dissolving lignin. The pulping process is mild without damaging cellulose. The cooked wheat straw fibres still present the configuration of natural cellulose. Further, there are many fine fibres in the pulp and larger spaces between the fibres, and the characteristics of this pulp are in accordance with those of nonwood fibre pulp.

\section{ACKNOWLEDGEMENTS}

The authors would like to thank the National Natural Science Foundation of China for providing financial support for this project (21176195).

\section{List of abbreviations and symbols Popis kratica i simbola}

\begin{tabular}{|c|c|}
\hline [Emim] $\mathrm{Br}$ & $\begin{array}{l}\text { - 1-ethyl-3-methylimidazolium bromide } \\
\text { - 1-etil-2-metilimidazolijev bromid }\end{array}$ \\
\hline $\mathrm{L}$ & $\begin{array}{l}\text { - liquid } \\
\text { - tekućina }\end{array}$ \\
\hline $\mathrm{S}$ & $\begin{array}{l}\text { - solid } \\
\text { - čvrsta tvar }\end{array}$ \\
\hline C & $\begin{array}{l}\text { - cellulose mass concentration, g/(100 ml) } \\
\text { - masena koncentracija celuloze, g/(100 ml) }\end{array}$ \\
\hline DP & $\begin{array}{l}\text { - polymerization degree } \\
\text { - stupanj polimerizacije }\end{array}$ \\
\hline$K$ & $\begin{array}{l}\text { - constant in eq. } 2 \\
\text { - konstanta u jedn. } 2\end{array}$ \\
\hline$m$ & $\begin{array}{l}\text { - mass, g } \\
\text { - masa, g }\end{array}$ \\
\hline$Y$ & $\begin{array}{l}\text { - yield, 1, \% } \\
\text { - iskorištenje, 1, \% }\end{array}$ \\
\hline$\eta$ & $\begin{array}{l}\text { - relative viscosity } \\
\text { - relativna viskoznost }\end{array}$ \\
\hline$[\eta]$ & $\begin{array}{l}\text { - intrinsic viscosity } \\
\text { - intrinzička viskoznost }\end{array}$ \\
\hline$\theta$ & $\begin{array}{l}\text { - Bragg angle, } \\
\text { - Braggov kut, }\end{array}$ \\
\hline
\end{tabular}

\section{References \\ Literatura}

1. S. J. Zhang, X. M. Liu, X. Q. Yao, Frontiers, progresses and applications of ionic liquids, Sci. China Press B: Chem. 39
(2009) 1134-1144.

2. Y. Zheng, X. P. Xuan, A. R. Xu, Dissolution and Separation of Lignocellulose with Room Temperature Ionic Liquids, Progress Chem. 21 (2009) 1807-1812.

3. C. F. Liu, W. Y. Li, R. C. Sun, J. Ye, Degradation and Homogeneous Derivatization of Cellulose in Room Temperature Ionic Liquid AmimCl, Paper Sci. Technol. 26 (2007) 37-40.

4. B. Li, F. Ilari, D. S. Argyropoulos, Acidolysis of Wood in Ionic Liquids, Ind. Eng. Chem. Res. 49 (2010) 3126-3136, doi: http://dx.doi.org/10.1021/ie1000983.

5. D. A. Fort, R. C. Remsing, R. P. Swatloski, Can ionic liquids dissolve wood processing and analysis of lignocellulosic materials with 1-n-butyl-3-methylimidazolium chloride, Green Chem. 9 (2007) 63-69, doi: http://dx.doi.org/10.1039/ B607614A.

6. C. Li, Pulping of rice straw high-boiling point organosolv solvents, World Pulp Paper 28 (2005) 14-17.

7. Y. H. Tian, D. C. Li, Study on the extracting technology of lignin from wheat straw by organic solvent, Hubei Agricultural Sci. 51 (2012) 1228-1231.

8. H. R. Gong, Application Results of Chelating Agents as Cooking Aids in Wheat Straw Pulping, Pap. Chem. 19 (2007) 26-28.

9. S. L. Shi, H. R. Hu, J. M. Liu, Experiments of Applying Cooking Aids to Non-Wood Fiber Pulping, Trans. China Pulp Pap. 20 (2005) 46-50.

10. F. Xu, R. C. Sun, H. Y. Zhan, Progress of Organosolv Pulping, Trans. China Pulp Pap. 19 (2004) 152-156.

11. L. Y. Cheng, T. X. Zhu, W. W. Liu, Investigation on Dissolution of Cellulose in Ionic Liquids, Synthetic Fiber in China 4 (2008) 9-13.

12. N. Keiichi, Relationship between Paper and our Environment, Japan Tappi J. 67 (2013) 1367-1371, doi: http://dx.doi. org/10.2524/jtappij.67.1367.

13. Y. J. Xu, J. Wang, Application of ionic liquids in the pulp and paper and the cellulose industries, China Pulp Pap. 30 (2011) 46-48.

14. H. B. Xie, A. King, I. Kilpelainen, Thorough chemical modification of wood-based lignocellulosic materials in ionic liquids, Biomacromolecules. 8 (2007) 3740-3748, doi: http:// dx.doi.org/10.1021/bm700679s.

15. Y. H. Liu, Y. Deng, Technical parameters of dissolution and separation of cottonstalk cellulose in ionic liquid, Trans. Chinese Soc. Agricult. Eng. (CSAE). 25 (2009) 259-263.

16. W. Zhai, H. Z. Chen, R. Y. Ma, Structural characteristics of cellulose after dissolution and regeneration from the ionic liquid [bmim]Cl, J. Beijing Univer. Chem. Technol. 34 (2007) 138-141.

17. S. Y. Tan, D. R. MacFarlane, Extraction of lignin from lignocellulose at atmospheric pressure using alkylbenzenesulfonate ionic liquid, Green Chem. 11 (2009) 339-345, doi: http:// dx.doi.org/10.1039/b815310h

18. R. P. Swatloski, S. K. Spear, R. D. Rogers, Dissolution of cellulose with ionic liquids, J. Am. Chem. Soc. 124 (2002) 49744975, doi: http://dx.doi.org/10.1021/ja025790m.

19. J. Kajimoto, Y. Sano, W. E. Widodo, HBS pulping (1) - pulping of softwood, Japan Tappi J. 54 (2000) 88-93, doi: http:// dx.doi.org/10.2524/jtappij.54.1252.

20. J. F. Liu, G. B. Jiang, Y. G. Chi, Use of ionic liquids for liquid-phase microextraction of polycyclic aromatic hydrocarbons, Anal. Chem. 75 (2003) 5870-5876. 


\title{
SAŽETAK \\ Priprava pulpe obradom pšenične slame ionskom tekućinom 1-etil-3-metilimidazolijevim bromidom
}

\author{
Wei Song, ${ }^{\text {a }}$ Yu Deng ${ }^{b^{*}}$ i Hong Zhu
}

Prikazana je priprava pulpe obradom pšenične slame ionskom tekućinom 1-etil-3-metilimidazolijevim bromidom ([Emim]Br). Optimalni uvjeti za pripravu pulpe nađeni su analizom rezultata jednofaktorskih i ortogonalnih eksperimenata. Prosječno iskorištenje pulpe iznosi $44 \%$, a prosječni povrat ionske tekućine 93,5\%. Prema rendgenskoj difrakcijskoj analizi nema vidljivih razlika u kristalnoj strukturi celuloze, a snimci SEM-om pokazuju da u pulpi ima mnogo finih vlakana te da su velike udaljenosti među vlaknima.

\section{Ključne riječi}

Priprava pulpe, iskorištenje pulpe, ionska tekućina, povrat, pšenična slama

a Tianjin Key Laboratory for Control Theory \& Applications in Complicated Systems, Tianjin University of Technology, Tianjin, 300 384, Kina

b Tianjin Key Laboratory of Pulp \& Paper, Tianjin University of Science \&Technology, Tianjin, 300 457, Kina

' Institute of Biology and Environment Engineering, Tianjin Vocational Institute, Tianjin, 300 410, Kina
Izvorni znanstveni rad Prispjelo 2. rujna 2016. Prihvaćeno 10. listopada 2016. 